\title{
Evaluation of propolis to modify soft denture lining materials, part I
}

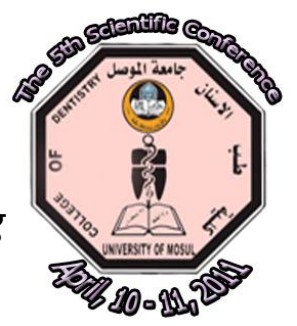

\section{ABSTRACT}

\section{AIMS}

Aims to evaluate some properties of temporary soft liner (Bony plus) and permanent soft liner (vertex) before and after adding propolis extracts to it. Materials and methods ethanolic extracts of propolis(ethanolic extract of propolis) was added to temporary soft liner (Bony plus), and glycolic extract of propolis(glycolic extract of propolis) was added to permanent soft liner (vertex), then the volumetric dimensional changes, hardness, water absorption and solubility were evaluate, the total samples were (128). Results showed the presence of significant diffrence in the Hardness, Water absorption and Solubility of the modified soft liners (After adding propolis to it), and there was no significant diffrence in the volume of the soft liners before and after adding propolis.Conclusions the volumetric changes of modified and control group of permanent soft liner (vertex) was no significantly different, The modification type (for both permanent and temporary) of soft liner was significantly softer than the control group along the period of storage (1 month) and the modification type (for both permanent and temporary) of soft liner was significantly have more water absorption and solubility than the control group along the period of storage (1 month).

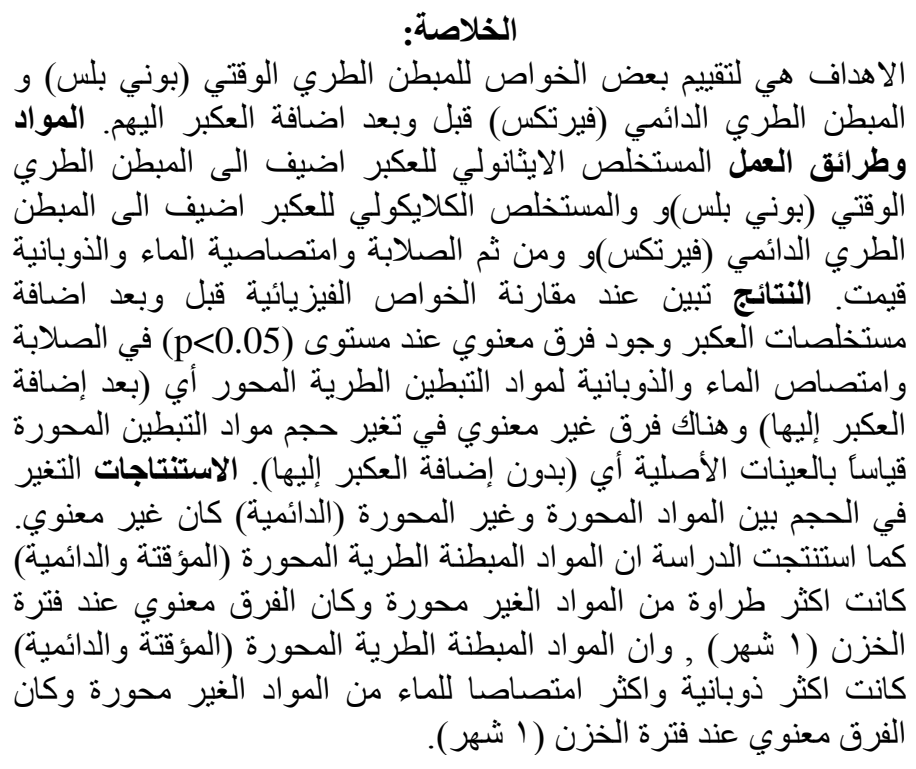

*Assistant Professor. Prosthetic department, college of dentistry, Mosul university, Iraq ** Professor. college of science, Mosul university, Iraq Prosthetic department, college of dentistry Mosul university, Iraq ***Asst lect.

Prosthetic dep.

Mosul university.
Ammar K. AL-Nori $B D s$, $M S c$.* Bassima A. Abdullah BSs, MSc Phd.**, Hamza S. AL-neema $B D s$, $M S c$.***

Key words: Propolis, soft liner, hardness. 
ropolis, sometimes also referred to "bee glue", is the generic name of

resinous substance collected by honeybees from various plant sources ${ }^{(1)}$. The word propolis is derived from the Greek, pro - for/or defense and polis -, the city, that

is: defense of the city (or the hive) ${ }^{(2)}$. Propolis is a strong adhesive resinous substance collected, transformed and used by bees to seal holes in their honeycombs, smooth out the internal walls and protect the entrance against intruders ${ }^{(3)}$.

Propolis has versatile biological activities, such as antibacterial ${ }^{(4)}$, antiviral $^{(5)}$, immunostimulating and anti-inflammatory ${ }^{(6)}$. It is thought to be an antitumor agent and it possibly presents a differentiation inducing agent ${ }^{(7)}$, anti oxidant properties, as well as successful clinical applications, which has brought a greater interest in propolis effects ${ }^{(8)}$.

Soft lining material may be defined as a soft, elastic and resilient material forming all or part of the fit (tissue) surface of a denture. It usually acts as a cushion between the hard denture base and the tissue, reducing the masticatory forces that are transmitted by the prosthesis to the underlying tissues. Nystatine containing liner is particularly useful in the treatment of denture stomatitis prior to the provision of new dentures, it is also valuable in those cases where denture stomatitis tends to resist conventional treatment because the patient is asked to remove his denture for long period of time during the treatment which will embarrass them ${ }^{(9)}$.

This kind of treatment is accomplished by adding an antifungal drug like Nystatine to the soft liner, so we get well fitting dentures in addition to the antifungal effect of the drug. This modified denture liner is as effective as the conventional therapy and has none of its drawbacks. Also it is relatively cheap, easy to prepare at the chairside and the total dose of Nystatin that it contains is very low ${ }^{(10)}$.

An alternative to drug and attempts to incorporate antifungal agents like propolis to act as antifungal agent. The aims of our research were to evaluate the effect of adding propolis on some properties (water absorption, solubility, and hardness) of the soft denture lining materials.

\section{MATERIALS AND METHODS}

Preparation of Alcoholic and Glycolic Extractions of Propolis: Ethanolic extract: the raw propolis was extract in an absolute ethanol alcohol in a cocenteration $30 \%$. ${ }^{(11,12)}$

Glycolic extract: the raw propolis was extract in a propylene glycol in a cocenteration $10 \%$. ${ }^{(11)}$

In this study we incorporate glycolic extract of propolis to the permanent soft liner (vertex) and ethanolic extract of propolis to the temporary soft lining (bony plus) to show the antifungal activity.

Bony plus soft liner: an $20 \mathrm{mg}$ of ethanolic extract of propolis was added for each 1 $\mathrm{ml}$ of the liquid (monomer) which consider as a solvent and after mixing the material was placed in the stone mold. Polyester film was placed on each side and the bony plus was sandwiched between two Polyester films and then cover the stone mold and pressed by a clamp until complete set of the material.

Permanent soft liner (vertex): glycolic extract of propolis was added to the soft lining material (vertex), after mixing the material according to the manufacturing instructions it placed in the stone mold. Polyester film was placed on each side and vertex soft lining was sandwiched between two Polyester films and then cover the stone mold and pressed by a clamp. After the specimens were polymerized in the water bath (according to the manufacturing instructions) the clamp remain in the hot water and leave to cool until it reach to $40^{\circ} \mathrm{C}$, the clamp was removed out of the hot

Journal of the $5^{\text {th }}$ Scientific Conference of Dentistry College, Apr. 2011 
water and open the two halves of the flask and open the two polyester films the soft lining material was coated by glycolic extract of propolis in a ratio of 1:1(it mean one $\mathrm{ml}$ of glycolic extract of propolis for each $\mathrm{ml}$ of the monomer) on each side of the specimens and the two half of the flasks closed again and put in the clamp and leave to cool until reach the room temperature.

\section{Volumetric Dimensional Changes of Modified Permanent Soft Denture Lining Material (vertex):}

Sixteen specimens of permanent soft liner (vertex) in a dimensions of $20 \mathrm{~mm} \times 30 \mathrm{~mm} \times 0.5 \mathrm{~mm}$ (width, length and thickness respectively) cured with specimens of hard denture base material (hard vertex heat cure) in a dimensions of $20 \mathrm{~mm} \times 30 \mathrm{~mm} \times 2 \mathrm{~mm}$ (width and length and thickness respectively) were made as a manner of 8 specimens made according to the manufacturer instructions that mean 1.5 hours in $70^{\circ} \mathrm{C}$ and 0.5 hour in $100{ }^{\circ} \mathrm{C}$ (vertex, Netherland), which considered as a (control group) and 8 specimens made in a modified procedure by adding glycolic extract of propolis which considered as a (modified group). Also another sixteen specimens of permanent soft liner (vertex) in a dimensions of $20 \mathrm{~mm} \times 30 \mathrm{~mm} \times 0.5 \mathrm{~mm}$ (width and length and thickness respectively) were cured alone, also made as a manner of 8 specimens made according to the manufacturer instructions which considered as a (control group) and 8 specimens made in a modified procedure by adding glycolic extraction of propolis which considered as a (modified group). After complete curing, the volumetric measurments of each specimen were calculated by using electronic vernea. The volume of two groups(control \& modified) was compared by using Independent $\mathrm{T}$ test.

\section{Water Absorption and Solubility:}

The specimens were prepared according to the American Dental Association (A.D.A) specification No.12 ${ }^{(12)}$ for denture base plastics which consisted of $0.5 \mathrm{~mm}$ thickness and $50 \mathrm{~mm}$ diameter discs.

For temporary soft liner (Bony plus) the materials were mixed according to the manufacturer instruction poured within the prepared mould (Aluminum disc of 50 mm diameter was put on the center of the sheet wax and by using a sharp knife, a circle of $50 \mathrm{~mm}$ diameter and $0.5 \mathrm{~mm}$ depth hole), then another glass slab placed over the prepared mould until setting.

For a modified type of propolis soft liner $20 \mathrm{mg}$ of ethanolic extract of propolis was dissolved in each $1 \mathrm{ml}$ of (Bony plus) liquid (monomer).

While for permanent soft liner (vertex) the materials were mixed according to the manufacturer instruction poured within the prepared mould $(50 \mathrm{~mm}$ in dimeter and $0.5 \mathrm{~mm}$ thickness) of stone between two layers of seloven nylon to produce a smooth surfaces on both sides of the specimens and cured in a water bath according to the manufacturer instruction. For a modified type of propolis soft liner, after complete the curing cycle the metal flask remain in the hot water until it reach $40^{\circ} \mathrm{C}$ then the two flasks opened and put glycolic extract of propolis between two nylon layers in a ratio of $1 \mathrm{ml}$ of glycolic extract of propolis for each $1 \mathrm{ml}$ of monomer. The specimen was removed by a twizer, excess slashes was cut with scalpel blade. Desiccation of the specimens over silica gel for $24 \mathrm{hrs}$. in thermostatically controlled incubator at $37^{\circ} \mathrm{C}$, and the specimens weighed using electronic sensitive balance; the weight recorded in grams. This was considered as the initial weight of the specimen (W1). Eight specimens for each group of soft lining materials were produced in this manner. The specimens immersed in distilled water in a tightly sealed container placed in thermostatically controlled incubator at $37 \mathrm{C}^{0}$. The specimens taken out from their containers by a twizer, excess water on the specimen was removed by blotting the 
specimen with a filter paper and then weighed (W2). This procedure was repeated at different intervals of time (after 1 day, 1 week, 2 weeks, and 1 month) from immersion in water. Desiccation of the specimens over silica gel for $24 \mathrm{hrs}$. in thermostatically controlled incubator at $37^{\circ} \mathrm{C}$, and the specimens weighed using electronic sensitive balance for many times until it reach the constant value (the two end readings are equal) it consider as (W3). This procedure was repeated at different intervals of time (after 1 day, 1 week,2weeks, and 1 month) from immersion in water.

Water absorption percentage and water solubility percentage were calculated similar to a method used by Kazanji and Watkinson ${ }^{(13)}$.

$$
\begin{aligned}
\text { Water absorption }(\%)= & \frac{\text { Weight after immersion }- \text { Weight after desiccation }}{\text { Initial weight }} \times 100 \\
& =\frac{W 2-W 3}{W 1} \times 100
\end{aligned}
$$

\section{Hardness:}

$$
\begin{aligned}
\text { Water solubility }(\%) & =\frac{\text { Initial weight }- \text { weight after desiccation }}{\text { Initial weight }} \times 100 \\
& =\frac{W 1-W 3}{W 1} \times 100
\end{aligned}
$$

The tested specimens of the soft lining material chosen for this experiment were of $4.5 \mathrm{~mm}$ thickness and of $25 \mathrm{~mm}$ in diameter circular discs bonded to a hard base of $2.5 \mathrm{~mm}$ thickness and $50 \mathrm{~mm}$ in diameter discs of cold cure acrylic base for temporary soft liner (Bony plus) and hot cure acrylic base for permanent soft liner vertex (14). The acrylic base was prepared using aluminum mould used by Kazanji and Watkinson (14) with some modification. It is used for temporary soft liner (Bony plus) specimens only. The aluminum mould consisted of a low cylindrical flask of $50 \mathrm{~mm}$ internal diameter, $63 \mathrm{~mm}$ external diameter and $7 \mathrm{~mm}$ internal height with a hole in the base of $10 \mathrm{~mm}$ diameter to aid in the removal of the acrylic base. Aluminum discs of the same internal diameter and of $0.5 \mathrm{~mm}$ thickness for each placed inside the mould in order to prepare the required thickness of the acrylic base. And an aluminum cover was constructed in order to cover the mould. In the center of the cover a threaded hole of $10 \mathrm{~mm}$ internal diameter, into which a screw was threaded. The height that the flat head could be lowered from the surface of the cover was adjusted by turning the screw by a hand. consisted of $0.5 \mathrm{~mm}$ thickness and $50 \mathrm{~mm}$ diameter discs, as shown in figure (1).

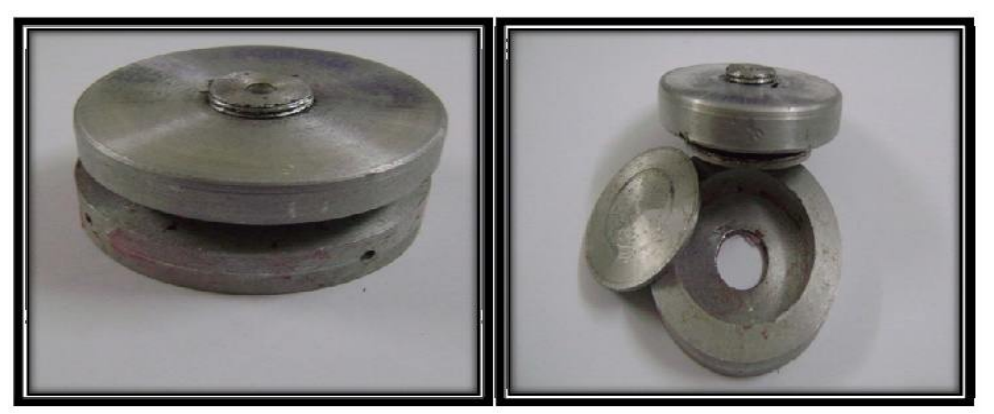

Figure (1) Aluminum mould for acrylic base resin 


\section{RESULTS \\ Volumetric Dimensional Changes of Modified Permanent Soft Denture Lining Material (vertex):}

The mean and standard deviation of the control group (without propolis) and modified group (with glycolic extract of propolis) of permanent soft liner (vertex) for the hard with soft liner and the t-test between the control and modified group were shown in the Table (1). It shown that there were no significant differences $(p<0.05)$ in the volume of the specimens of the control and modified group of permanent soft liner with the hard denture base (vertex). The mean and standard deviation of the control group (without propolis) and modified group (with glycolic extract of propolis) of permanent soft liner alone without hard denture base (vertex) for the soft liner only and the t-test between the control and modified group were shown in the Table (2). It shown that there were no significant differences $(p<0.05)$ in the volume of the specimens of the control and modified group of permanent soft liner (vertex).

Table (1). Descriptive statistic and t-test for volumetric dimensional changes for hard denture base with modified soft liner (glycolic extract of propolis).

\begin{tabular}{|c|c|c|c|c|c|c|}
\hline Groups & Number & Mean & $\begin{array}{c}\text { Standard } \\
\text { deviation }\end{array}$ & $\begin{array}{c}\text { T - } \\
\text { value }\end{array}$ & df & P - value \\
\cline { 1 - 5 } Control & 8 & 2289.288 & 50.971 & 1.739 & \multirow{2}{*}{14} & 0.14 \\
\hline Modified & 8 & 2166.876 & 192.415 & 1.73 \\
\hline
\end{tabular}

Table (2). Descriptive statistic and t-test for volumetric dimensional changes for modified soft liner (glycolic extract of propolis) only.

\begin{tabular}{|c|c|c|c|c|c|c|}
\hline Groups & Number & Mean & Standard deviation & T - value & df & P - value \\
\cline { 1 - 4 } Control & 8 & 2081.0837 & 50.971 & -.39 & \multirow{2}{*}{14} & .69 \\
\hline Modified & 8 & 2114.6925 & 171.58455 & & \\
\hline
\end{tabular}

\section{Water Absorption and Solubility \\ 1.For Bony Plus}

The mean and standard deviation of the control group (without propolis) and modified group (with ethanolic extract of propolis) of temporary soft liner (bony plus) were shown in the Table $(3,4,5)$. They are shown that the mean of water absorption of control group was less than that of modified group after 1 day, 1 week, and 2 weeks of immersion in D.W. which indicate that the modified group absorb more water than control group, also it shown that the solubility of modified group was more than that of control group after 1 day of immersion in the D.W.of the specimens of the control and modified group of temporary soft liner (bony plus). The t-test between the control and modified group show that were significant differences $(p<0.05)$ in the Water Absorption and Solubility after 1 day and 1 week of immersion in the D.W. and there were no significant differences $(p<0.05)$ in the Water Absorption and significant differences in the Solubility after 2 weeks of immersion in the D.W. of the specimens of the control and modified group of temporary soft liner (bony plus). While the table (6) show that the mean of water absorption after 1 month of immersion in D.W. of control group was more than the mean of modified group which indicate that the modified group absorb less water than control group, also the it shown that the solubility of modified group was less than the solubility of control group after 1 month of immersion in the D.W. of the specimens of the control and modified group of temporary soft liner (bony plus) after 1 month of immersion in the D.W. While 
the t-test between the control and modified group shown that were no significant differences $(p<0.05)$ in the Water Absorption and Solubility after 1 month of immersion in the D.W. of the specimens of the control and modified group of temporary soft liner (bony plus).

Table (3): Descriptive statistic and $\mathrm{t}$ - test for water absorption and solubility after 1 day for bony plus.

\begin{tabular}{|c|c|c|c|c|c|c|c|}
\hline & Groups & Number & Mean & $\begin{array}{c}\text { Standard } \\
\text { deviation }\end{array}$ & $\begin{array}{c}\text { T - } \\
\text { value }\end{array}$ & df & $\begin{array}{c}\text { P - } \\
\text { value }\end{array}$ \\
\hline $\begin{array}{c}\text { Water } \\
\text { absorption }\end{array}$ & Control & 8 & 8.766 & 2.751 & \multirow{2}{*}{9.286} & 14 & 0.000 \\
\cline { 2 - 8 } Solubility & Codified & 8 & 26.142 & 4.521 & \multirow{2}{*}{4.746} & 14 & 0.000 \\
\cline { 2 - 9 } & Modified & 8 & 7.529 & 3.771 & 1.057 & 0.804 & \\
\hline
\end{tabular}

Table (4): Descriptive statistic and T - test for water absorption and solubility after 1 week for bony plus.

\begin{tabular}{|c|c|c|c|c|c|c|c|}
\hline & Groups & Number & Mean & $\begin{array}{l}\text { Standard } \\
\text { deviation }\end{array}$ & $\begin{array}{c}\text { T - } \\
\text { value }\end{array}$ & df & $\begin{array}{c}P \text { - } \\
\text { value }\end{array}$ \\
\hline \multirow{2}{*}{$\begin{array}{l}\text { Water } \\
\text { absorption }\end{array}$} & Control & 8 & 7.747 & 2.837 & \multirow{2}{*}{-9.747} & \multirow{2}{*}{14} & \multirow{2}{*}{0.000} \\
\hline & Modified & 8 & 26.142 & 4.521 & & & \\
\hline \multirow{2}{*}{ Solubility } & Control & 8 & 1.157 & 0.525 & \multirow{2}{*}{-4.732} & \multirow{2}{*}{14} & \multirow{2}{*}{0.000} \\
\hline & Modified & 8 & 7.529 & 3.771 & & & \\
\hline
\end{tabular}

Table (5): Descriptive statistic and $\mathrm{t}$ - test for water absorption and solubility after 2 weeks for bony plus.

\begin{tabular}{|c|c|c|c|c|c|c|c|}
\hline & Groups & Number & Mean & $\begin{array}{l}\text { Standard } \\
\text { deviation }\end{array}$ & $\begin{array}{c}\text { T - } \\
\text { value }\end{array}$ & df & $\begin{array}{c}P \text { - } \\
\text { value }\end{array}$ \\
\hline \multirow{2}{*}{$\begin{array}{l}\text { Water } \\
\text { absorption }\end{array}$} & Control & 8 & 4.312 & 2.358 & \multirow{2}{*}{0.182} & \multirow{2}{*}{14} & \multirow{2}{*}{0.858} \\
\hline & Modified & 8 & 4.599 & 3.770 & & & \\
\hline \multirow{2}{*}{ Solubility } & Control & 8 & 8.623 & 1.617 & \multirow{2}{*}{7.414} & \multirow{2}{*}{14} & \multirow{2}{*}{0.000} \\
\hline & Modified & 8 & 18.026 & 3.201 & & & \\
\hline
\end{tabular}

Table (6):Descriptive statistic and $\mathrm{t}$-test for water absorption and solubility after 1 month for bony plus.

\begin{tabular}{|c|c|c|c|c|c|c|c|}
\hline & Groups & Number & Mean & $\begin{array}{l}\text { Standard } \\
\text { deviation }\end{array}$ & $\begin{array}{c}\text { T - } \\
\text { value }\end{array}$ & df & $\begin{array}{c}P \text { - } \\
\text { value }\end{array}$ \\
\hline \multirow{2}{*}{$\begin{array}{l}\text { Water } \\
\text { absorption }\end{array}$} & Control & 8 & 7.6145 & 3.46949 & \multirow{2}{*}{.76} & \multirow{2}{*}{14} & \multirow{2}{*}{.45} \\
\hline & Modified & 8 & 6.2377 & 3.75085 & & & \\
\hline \multirow{2}{*}{ Solubility } & Control & 8 & 22.6431 & 19.51926 & \multirow{2}{*}{.50} & \multirow{2}{*}{14} & \multirow{2}{*}{.62} \\
\hline & Modified & 8 & 19.1681 & 2.37146 & & & \\
\hline
\end{tabular}

\section{For Vertex}

The mean and standard deviation of the control group (without propolis) and modified group (with GEP) of permanent soft liner (vertex) were shown in the tables $(7,8,9,10)$. They were shown that the mean of water absorption and the solubility of control group and the mean of modified group were approximately equal after 1 day of immersion in the D.W. and of the specimens of the control and modified group of permanent soft liner (vertex). And the mean of water absorption of control group was less than the mean of modified group which indicate that the modified group absorb more water than control group, also the it shown that the solubility of modified group was higher than the solubility of control group after 1 week and 2 weeks and 1 month 
of immersion in the D.W. While the t-test between the control and modified group shown that were no significant differences $(p<0.05)$ in the Water Absorption and Solubility after 1 day of immersion in the D.W. The t-test between the control and modified group shown that there were no significant differences $(\mathrm{p}<0.05)$ in the Water Absorption and there were significant differences $(p<0.05)$ in the Solubility after 1 week, 2 weeks, and 1 month of immersion in the D.W..of the specimens of the control and modified group of permanent soft liner (vertex).

Table (7): Descriptive statistic and t -test for water absorption and solubility after 1 day for vertex.

\begin{tabular}{|c|c|c|c|c|c|c|c|}
\hline \multicolumn{8}{|c|}{ Frover } \\
\hline & Groups & Number & Mean & $\begin{array}{l}\text { Standard } \\
\text { deviation }\end{array}$ & $\begin{array}{c}\text { T - } \\
\text { value }\end{array}$ & df & $\begin{array}{c}P \text { - } \\
\text { value }\end{array}$ \\
\hline \multirow{2}{*}{$\begin{array}{l}\text { Water } \\
\text { absorption }\end{array}$} & Control & 8 & 2.2738 & .99225 & \multirow{2}{*}{.11} & \multirow{2}{*}{14} & \multirow{2}{*}{.91} \\
\hline & Modified & 8 & 2.3242 & .82550 & & & \\
\hline \multirow{2}{*}{ Solubility } & Control & 8 & 3787 & .28285 & \multirow{2}{*}{-.10} & \multirow{2}{*}{14} & \multirow{2}{*}{.92} \\
\hline & Modified & 8 & .3666 & .18908 & & & \\
\hline
\end{tabular}

Table (8): Descriptive statistic and t test for water absorption and solubility after 1 week for

\begin{tabular}{|c|c|c|c|c|c|c|c|}
\hline & Groups & Number & Mean & $\begin{array}{l}\text { Standard } \\
\text { deviation }\end{array}$ & $\begin{array}{c}\text { T - } \\
\text { value }\end{array}$ & df & $\begin{array}{c}P \text { - } \\
\text { value }\end{array}$ \\
\hline \multirow{2}{*}{$\begin{array}{l}\text { Water } \\
\text { absorption }\end{array}$} & Control & 8 & 10894 & 0.308 & \multirow{2}{*}{-1.711} & \multirow{2}{*}{14} & \multirow{2}{*}{0.109} \\
\hline & Modified & 8 & 2.258 & 0.516 & & & \\
\hline \multirow{2}{*}{ Solubility } & Control & 8 & 0.266 & 0.162 & \multirow{2}{*}{-2.530} & \multirow{2}{*}{14} & \multirow{2}{*}{0.024} \\
\hline & Modified & 8 & 0.639 & 0.382 & & & \\
\hline
\end{tabular}

Table (9): Descriptive statistic for water absorption and solubility after 2 weeks for vertex.

\begin{tabular}{|c|c|c|c|c|c|c|c|}
\hline 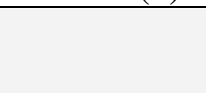 & Groups & Number & Mean & $\begin{array}{l}\text { Standard } \\
\text { deviation }\end{array}$ & $\begin{array}{c}\text { T - } \\
\text { value }\end{array}$ & df & $\begin{array}{c}\mathrm{P} \text { - } \\
\text { value }\end{array}$ \\
\hline \multirow{2}{*}{$\begin{array}{l}\text { Water } \\
\text { absorption }\end{array}$} & Control & 8 & 1.384 & 0.347 & \multirow{2}{*}{-1.402} & \multirow{2}{*}{14} & \multirow{2}{*}{0.183} \\
\hline & Modified & 8 & 1.609 & 0.290 & & & \\
\hline \multirow{2}{*}{ Solubility } & Control & 8 & 0.205 & 0.120 & \multirow{2}{*}{-3.132} & \multirow{2}{*}{14} & \multirow{2}{*}{0.007} \\
\hline & Modified & 8 & 0.672 & 0.403 & & & \\
\hline
\end{tabular}

Table (10): Descriptive statistic and t-test for water absorption and solubility after 1 month for

\begin{tabular}{|c|c|c|c|c|c|c|c|}
\hline & Groups & Number & Mean & $\begin{array}{l}\text { Standard } \\
\text { deviation }\end{array}$ & $\begin{array}{c}\mathrm{T} \text { - } \\
\text { value }\end{array}$ & df & $\begin{array}{c}P \text { - } \\
\text { value }\end{array}$ \\
\hline \multirow{2}{*}{$\begin{array}{l}\text { Water } \\
\text { absorption }\end{array}$} & Control & 8 & 1.4775 & .31620 & \multirow{2}{*}{-.77} & \multirow{2}{*}{14} & \multirow{2}{*}{.452} \\
\hline & Modified & 8 & 1.6003 & .31978 & & & \\
\hline \multirow{2}{*}{ Solubility } & Control & 8 & .2911 & .15458 & \multirow{2}{*}{-3.26} & \multirow{2}{*}{14} & \multirow{2}{*}{.006} \\
\hline & Modified & 8 & .8390 & .44879 & & & \\
\hline
\end{tabular}

\section{Hardness Test:}

\section{For Bony plus and vertex after 1 day}

The table (11) show that the mean of the modified group for both types of soft liners were less than the mean of the control group for both types of soft liners which indicate that the modified group are softer than the control group for both types of soft liners after 1 day of immersion in the D.W. The t-test between the control and modified group (for both types -permanent and temporary soft liners) shown that 
there were significant differences $(\mathrm{p}<0.05)$ in the Hardness after 1 day of immersion in the D.W.of the specimens of the control and modified group of permanent soft liner (vertex), and temporary soft liner(bony plus).

Table (11): Descriptive statistic and t-test for hardness test after 1 day for bony plus and vertex.

\begin{tabular}{|c|c|c|c|c|c|c|c|}
\hline & Groups & Number & Mean & $\begin{array}{l}\text { Standard } \\
\text { deviation }\end{array}$ & $\begin{array}{c}\mathrm{T} \text { - } \\
\text { value }\end{array}$ & df & $\begin{array}{c}P \text { - } \\
\text { value }\end{array}$ \\
\hline \multirow[t]{2}{*}{ Control } & Bony plus & 8 & 31.746 & 0.509 & \multirow{2}{*}{5.870} & \multirow{2}{*}{14} & \multirow{2}{*}{0.000} \\
\hline & Vertex & 8 & 41.080 & 2.058 & & & \\
\hline \multirow[t]{2}{*}{ Modified } & Bony plus & 8 & 30.681 & 0.60 & \multirow{2}{*}{4.870} & \multirow{2}{*}{14} & \multirow{2}{*}{0.000} \\
\hline & Vertex & 8 & 36.538 & 1.649 & & & \\
\hline
\end{tabular}

\section{For bony plus and vertex After 1 week}

The table (12) show that the mean of the modified group for permanent types of soft liners(vertex) were less than the mean of the control group it indicate that the modified group softer than the control group after 1 week of immersion in the D.W. while the means of the control and modified group of temporary soft liner (bony plus) were approximately equal after 1 week of immersion in the D.W.

The t-test between the control and modified group (for both types -permanent and temporary soft liners) shown that there were no significant differences $(\mathrm{p}<0.05)$ in the Hardness after 1 week of immersion in the D.W.of the specimens of the control and modified group of permanent soft liner (vertex), and temporary soft liner(bony plus).

Table (12): Descriptive statistic and t-test for hardness test after 1 week for bony plus and vertex

\begin{tabular}{|c|c|c|c|c|c|c|c|}
\hline & Groups & Number & Mean & $\begin{array}{l}\text { Standard } \\
\text { deviation }\end{array}$ & $\begin{array}{c}\text { T - } \\
\text { value }\end{array}$ & df & $\begin{array}{c}P \text { - } \\
\text { value }\end{array}$ \\
\hline \multirow{2}{*}{ Control } & Bony plus & 8 & 44.206 & 5.825 & \multirow{2}{*}{-0.033} & \multirow{2}{*}{14} & \multirow{2}{*}{0.974} \\
\hline & Vertex & 8 & 47.850 & 2.834 & & & \\
\hline \multirow{2}{*}{ Modified } & Bony plus & 8 & 44.291 & 4.300 & \multirow{2}{*}{1.727} & \multirow{2}{*}{14} & \multirow{2}{*}{0.106} \\
\hline & Vertex & 8 & 45.331 & 2.997 & & & \\
\hline
\end{tabular}

\section{For bony plus and vertex After 2 weeks}

The table (13) show that the mean of the modified group for permanent types of soft liners(vertex) were less than the mean of the control group, it indicate that the modified group softer than the control group after 2 weeks of immersion in the D.W. while the mean of the control group of temporary soft liner (bony plus) were higher than the mean of the modified group after 2 weeks of immersion in the D.W. i.e. the control group was harder. The t-test between the control and modified group (for both types -permanent and temporary soft liners) shown that there were significant differences $(p<0.05)$ in the Hardness after 2 weeks of immersion in the D.W. of the specimens of the control and modified group of permanent soft liner (vertex), and there were no significant differences $(p<0.05)$ in the Hardness after 2 weeks of immersion in the D.W. of the specimens of the control and modified group of temporary soft liner(bony plus). 
Table (13): Descriptive statistic and t -test for hardness test after 2 weeks for bony plus and vertex

\begin{tabular}{|c|c|c|c|c|c|c|c|}
\hline & Groups & Number & Mean & $\begin{array}{l}\text { Standard } \\
\text { deviation }\end{array}$ & $\begin{array}{c}\mathrm{T} \text { - } \\
\text { value }\end{array}$ & df & $\begin{array}{c}P \text { - } \\
\text { value }\end{array}$ \\
\hline \multirow{2}{*}{ Control } & Bony plus & 8 & 52.050 & 7.319 & \multirow{2}{*}{0.801} & \multirow{2}{*}{14} & \multirow{2}{*}{0.437} \\
\hline & Vertex & 8 & 46.600 & 1.052 & & & \\
\hline \multirow{2}{*}{ Modified } & Bony plus & 8 & 49.863 & 2.476 & \multirow{2}{*}{2.754} & \multirow{2}{*}{14} & \multirow{2}{*}{0.016} \\
\hline & Vertex & 8 & 43.955 & 2.503 & & & \\
\hline
\end{tabular}

\section{For bony plus and vertex After 1 month}

The Table (14) show that the mean of the modified group for permanent types of soft liners(vertex) were less than the mean of the control group, it indicate that the modified group softer than the control group after 1 month of immersion in the D.W. while the mean of the control group of temporary soft liner (bony plus) were higher than the mean of the modified group after 1 month of immersion in the D.W. i.e. the control group was harder. The t-test between the control and modified group (for both types -permanent and temporary soft liners) shown that there were significant differences $(\mathrm{p}<0.05)$ in the Hardness after 1 month of immersion in the D.W.of the specimens of the control and modified group of permanent soft liner (vertex), and there were no significant differences $(p<0.05)$ in the Hardness after 1 month of immersion in the D.W.of the specimens of the control and modified group of temporary soft liner(bony plus).

Table (14). Descriptive statistic and t -test for hardness test after 1 month for bony plus and vertex

\begin{tabular}{|c|c|c|c|c|c|c|c|}
\hline & Groups & Number & Mean & $\begin{array}{l}\text { Standard } \\
\text { deviation }\end{array}$ & $\begin{array}{c}\text { T - } \\
\text { value }\end{array}$ & df & $\begin{array}{c}\mathbf{P} \text { - } \\
\text { value }\end{array}$ \\
\hline \multirow{2}{*}{ Control } & Bony plus & 8 & 61.498 & 4.121 & \multirow{2}{*}{1.585} & \multirow{2}{*}{14} & \multirow{2}{*}{0.135} \\
\hline & Vertex & 8 & 49.705 & 2.722 & & & \\
\hline \multirow{2}{*}{ Modified } & Bony plus & 8 & 58.371 & 3.760 & \multirow{2}{*}{2.686} & \multirow{2}{*}{14} & \multirow{2}{*}{0.018} \\
\hline & Vertex & 8 & 46.580 & 1.847 & & & \\
\hline
\end{tabular}

\section{DISCUSSION}

In this study was observed that the modified type of soft liner (permanent and temporary) have more water absorption than the control group and have higher solubility, but the softness of the modified type will increase among the four storage time in D.W. in compare with the control group, especially the permanent one (vertex).The explanation of this may be attributed to the reduce leaching of the plasticizer ,this is in agreement with the finding of Malmstrom ${ }^{(15)}$ when their results showed that the surface coated tissue conditioner retain their softness longer than the un coated group but it is in dis agreement with study of Wright et al., (1998) ${ }^{(16)}$ who carried the primary study on the soft lining material, he stated that although the loss of plasticizer of the acrylic soft lining was approximately equivalent to the replacement by water, it would lead the material to become hard and unsuitable for the purpose for which it was intended. 
The explanation of high water absorption and solubility of modified soft liner may be due to the presence of propolis itself that may increase the uptake of water and its component may be more soluble in water lead to increase the solubility of modified soft liner. In this study we wanted to clarify the effect of storage in D.W. at $37^{\circ} \mathrm{C}$ during 1 month, on the water absorption, solubility and hardness of the soft liner groups of this study( modified, control and temporary, permanent). The water absorption and solubility of 2 resilient denture liners was determined by absorption and solubility test, and softness of the resilient denture liners was measured as resistance to indentation by a shore-A-Durameter in a material for the 4 test periods; however, this in vitro study could provide preliminary information regarding the materials, based on water absorption, solubility and hardness test results.

Acrylic-based denture reline materials (vertex and bony plus) are known to degrade over time by water uptake and leaching out of plasticizers, which are usually low molecular weight esters such as dibutylphthalate ${ }^{(17)}$.

\section{CONCLUSIONS}

1. The volumetric changes of modified and control group of permanent soft liner (vertex) was no significantly different.

2. The modification type (for both permanent and temporary) of soft liner was significantly softer than the control group along the period of storage (1 month).

3. The modification type (for both permanent and temporary) of soft liner was significantly have more water absorption and solubility than the control group along the period of storage (1 month).

\section{REFERENCES}

1. Bankova V. Determining quality in propolis samples. J Am Apither Soc. 2000; 7(2):50-55.

2. Ghisalberti EL. Propolis: a review. Bee World. 1979; 60: 59 - 84.

3. Burdock G.A. Review of the biological properties and toxicity of bee propolis (propolis). Food Chem Toxicol.1998; 36: $347-363$.

4. Kujumgiev A, Bankova V, Ignatova A. Antibacterial activity of propolis, some of its components and their analogues. Pharmazie 1993.; 48: 785 - 786.

5. SerkedjievaJ and Manolova N . Anti - influenza virus effect of some propolis constituents and their analogues (esters of substituted cinnamic acids). J Nat Prod. 1992; 55: 294 - 297.

6. Dimov V, Ivanovska N, Monolova N, Bankova V, Nikolov S . Immunomodulatory action of propolis. Influence on anti - infections protection and macrophage function. Apidologie. 1991; 22: 155 - 162.

7. Guarini L, Su Z, Zucker S, Lin J, Grungerger D, Fisher P. Growth inhibition and modulation of antigenic phenotype in human melanoma and glioblastoma multiform cells by caffeic acid phenethyl ester (CAPE). Cell Mol Biol.1992; 38: 513 - 527.

8. Sudina GF, Mirzoeva OK, Pushkareva MA, Korshunova GA, Sumbatyan NV, Var folomeev SD . Caffeic acid phenethyl ester as a lipoxygenase inhibitor with antioxidant properties. Feds Lett. 1993; 329: $21-24$

9. Wright PS. Composition and properties of soft lining materials for acrylic dentures. J Dent. 1981; 9(3): $210-223$.

10. Thomas CJ and Nutt GM (). The in vitro fungicidal properties of visco - gel, alone and combined with nystatin and amphotericin B. J Oral Rahabil. 1978 (5): 167 - 172.

11. Krell RA . Value - added products from beekeeping. FAO Agricultural Services Bulletin .1996 N․ 124. Rome, Italy.

12. Lu., Chen. And Chou $\mathrm{Ch}$.Antibacterial activity of propolis against Staphylococcus aureus. Inter J Food Microbiology. 2005 102: 213 - 220.

13. American Dental Association. Guide to dental materials and devices. $7^{\text {th }}$ ed.chicago. 1975; Pp:203208.

14. Kazanji MNM and Watkinson AC. Soft lining materials: their absorption of and solubility in artificial saliva. Br Dent J. 1988; 165: 91 - 94.

15. Malmstrom HS, Mehta N, Sanchez R, Moss ME).The effect of two different coatings on the surface integrity and softness of a tissue conditioner. J Prosthet Dent. 2002; 87: 153 - 157.

Journal of the $5^{\text {th }}$ Scientific Conference of Dentistry College, Apr. 2011 
16. Wright, K, Young P, Riggs S, Parker R. Evaluating the effect of soft lining materials on the growth of yeast. J Prosthet Dent. 1998, 79(4), 404-409.

17. Gregory R and Frederick A .In vitro hardness, water sorption and resin solubility of laboratory processed and auto - polymerized long - term resilient liners over one year of water storage. J Prosthet Dent. 2002; 88: 139 - 144. 